\title{
The politics of the alcohol taxation system in Thailand: The behaviors of three major alcohol companies from 1992 to 2012
}

\author{
Bundit Sornpaisarn ${ }^{1,2,3}$ and Chuthaporn Kaewmungkun ${ }^{1}$ \\ ${ }^{1}$ Center for Alcohol Studies, Thailand \\ ${ }^{2}$ Department of Mental Health, Ministry of Public Health, Thailand \\ ${ }^{3}$ WHO/PAHO Collaboration Centre for Mental Health \& Addiction, Centre for Addiction and Mental Health, Canada
}

\begin{abstract}
Aim: This study aims to describe the political strategies influencing alcohol taxation in Thailand from 1992 to 2012.

Design: This study employs a case study research design, using a mix of qualitative and quantitative data analysis.

Setting: Thailand.

Findings: Three major companies comprise $92 \%$ of the Thai alcohol market, making it an oligopoly market. Ten increases of the alcohol tax rate occurred in Thailand from1992 to 2012, and the Thai government employed differential tax rate policies that favored four of eight beverage categories. These four beverage categories were produced mainly by one of the above-noted companies. Two significant events suggest that the other two companies tried to influence the Thai Prime Minister in 2005 and the Thai Parliament in 2007 to change the alcohol taxation method in order to favor the positioning of their products. As well, evidence revealed that alcohol companies had over-produced their products before three of the eight alcohol taxation increases from 1997 to 2009.
\end{abstract}

Conclusions: Both domestic and international large alcohol companies in Thailand have exerted significant political influence on the Thai alcohol taxation system. This influence is exemplified by the Thai government's differential alcohol tax rate policy, which favors their products; their ability to stockpile products before taxation increases; and their ability to challenge the Thai taxation system at the national level.

\section{The Influence of the Alcohol Industry on the Policy Process}

Alcohol taxation is one of the most effective alcohol control measures (Babor et al., 2010; World Health Organization, 2010a). It can reduce alcohol consumption in high-income countries (Elder et al., 2010; Wagenaar, Salois, \& Komro, 2009) and in low- and middle-income countries (Sornpaisarn, Shield, Cohen, Schwartz, \& Rehm, 2013). However, state policy choices are not made solely to achieve the end result of alcohol consumption and harm control; politics also shapes the policy decision-making process (Schlager \& Blomquist, 1996). Evidence indicates that the alcohol industry has influenced agenda setting for national alcohol policies in some countries, including the U.K. (Babor, 2004; Hawkins, Holden, \& McCambridge, 2012; Room, 2004), Hong Kong (Yoon \& Lam, 2012), Lesotho, Malawi, Uganda and Botswana (Tesler \& Malone, 2008).
The alcohol industry is commonly involved in the policy drafting process (Tesler \& Malone, 2008), uses corporate social responsibility (CSR) activities to frame its policyrelated activities (Babor \& Robaina, 2013; Hastings, 2013), funds and leads research to favor its interests (Babor, 2006; Jernigan, 2012; McCambridge, Hawkins, \& Holden, 2013), frames alcohol problems as exclusive to the heaviest drinkers (Hawkins \& Holden, 2013) and ultimately advocates for policies that are less effective in controlling alcohol sales and advertising (Babor, 2004; Baggott, 2010; Giesbrecht, 2006; Hawkins \& Holden, 2013; Hawks, 1993; Room, 2004) and that address various forms of selfregulation (Hawkins \& Holden, 2014). To exert influence, the alcohol industry usually establishes long-term personal relationships with policy makers and becomes involved in the provision and interpretation of information in both official and private meetings. In this manner, industry officials successfully position themselves as key stakeholders in the policy process who will be consulted on policy developments as a matter of course (Hawkins \& Holden, 2014; McCambridge, Hawkins, \& Holden, 2014).

Correspondence: Bundit Sornpaisarn, 99/8 Ngamduplee, Thung Maha Mek, Sathorn, Bangkok 10120, Thailand; Telephone: 6692-270-5088; E-mail: bundit.sornpaisarn@yahoo.com

Financial support:. The Centre for Alcohol Studies, the Thai Health Promotion Foundation, and the Department of Mental Health, Ministry of Public Health, Thailand.

Keywords: alcohol, middle-income country, oligopoly, policy, politics, tax 


\section{Alcohol-Related Problems and the Alcohol Taxation System in Thailand}

Thailand faces alcohol-related problems similar to those in other countries. Alcohol was greatest risk factor for disease in Thailand in 2009 (Kunnathum, Makka, Aungkulanon, Amornvisaisoradej, \& Nundhamcharoen, 2013), and economic costs from alcohol amounted to $1.3 \%$ of gross domestic product adjusted for purchasing power parity (GDP-PPP) in Thailand in 2006 (Rehm et al., 2009). Thus, effective alcohol control measures, such as taxation, are needed.

To address the burdens caused by alcohol, Thailand applies a unique form of alcohol excise tax known as Two-ChosenOne (2C1), which is a combination taxation method that the WHO Technical Manual on Tobacco Tax Administration defines as "Ad Valorem with Specific Floor Taxation" (World Health Organization, 2010b) (See Sornpaisarn, Shield, \& Rehm, 2012a; 2012b for details of 2C1 taxation).

Alcohol taxation rates are based on beverage categories as defined by the Thai Excise Department (Sornpaisarn, Shield, \& Rehm, 2012a). The Thai Excise Department divides alcoholic beverages into eight categories based on production method and ingredients (Thailand Government Gazette, 1950): beer, wine, community-fermented beverages, white spirits, mixed spirits, special blend spirits, brandy, and whisky.

\section{The Thai Alcohol Market Structure and Major Alcohol Companies}

Based on production and importation data from the Excise Department (2012a) (in terms of liters of pure alcohol per capita), the Thai alcohol market in 2009 consisted of 46\% domestic spirits, $13 \%$ imported whiskies, $40 \%$ beer, $0.8 \%$ wine, and $0.01 \%$ community-fermented beverages (see Table 1). Table 1 also indicates that three major alcohol companies accounted for $92 \%$ of the Thai alcohol market value from 2008 to 2011 (Manager Weekly Magazine, 2011; Marketeer, 2008), whereas products from other domestic and international alcohol companies collectively constituted only $8 \%$ of the total market value. A market structure that is composed of only a few major companies is called an oligopoly market (Keen, 1998). Products from
Company A, the largest domestic alcohol company, accounted for 85 to $93 \%$ of the domestic spirit market value (Manager Weekly Magazine, 2011) and 37\% of the beer market value (Marketeer, 2008), and its weighted sum was $56 \%$ of the total alcohol market value. Company B, the largest domestic beer company, produced $57 \%$ of the beer market value (Marketeer, 2008), which accounted for $23 \%$ of the total alcohol market value. Group C, a group of alcohol importation companies, imported and sold all of the imported whisky in Thailand, which accounted for $13 \%$ of the total alcohol market value.

There has not yet been a study examining the political interactions between the actors in the alcohol industry (Holden, Hawkins, \& McCambridge, 2012), and, accordingly, this study aims to describe the political strategies engaged in by major alcohol companies to influence alcohol taxation in Thailand from 1992 to 2012. We hypothesize that Company A, Company B, and Group $C$ aimed to (1) manipulate the Thai government to determine tax rates in favor of their products, (2) overproduce their products before tax rates increased, and (3) advocate for the alcohol excise taxation method that favored the positions of their alcohol products.

\section{Methods}

This study employed a case study design using a mix of qualitative and quantitative methods.

\section{Data Source to Analyze the Differential Tax Rate Policy}

The pattern of alcohol excise tax rate increases from 1992 to 2012 was used to analyze the tax rate determination policy. The proportions of the current rate to the ceiling rate for each of the eight alcoholic beverage categories were compared, to ascertain whether the government determined tax rates in favor of any particular alcohol product. The 1992 to 2012 period was chosen for study because the Thai government determined equal tax rates for the eight beverage categories in 1992 (Sornpaisarn, Kaewmungkun, \& Wattanaporn, 2010).

Table 1

Alcohol market share and corporate share of the alcohol market in Thailand, 2008-2009

\begin{tabular}{|c|c|c|c|c|c|c|}
\hline \multirow[b]{2}{*}{$\begin{array}{l}\text { (\% of total alcohol market) } \\
\text { Company }\end{array}$} & \multicolumn{6}{|c|}{$\begin{array}{c}\text { Corporate share } \\
\text { (Percentage of the total market value of each alcohol category) }\end{array}$} \\
\hline & $\begin{array}{l}\text { Domestic } \\
\text { spirits } \\
(46 \%)\end{array}$ & $\begin{array}{c}\text { Imported } \\
\text { whiskies } \\
(13 \%)\end{array}$ & $\begin{array}{l}\text { Beer } \\
(40 \%)\end{array}$ & $\begin{array}{l}\text { Wine } \\
(0.8 \%)\end{array}$ & $\begin{array}{c}\text { Community-fermented } \\
\text { beverages } \\
(0.01 \%)\end{array}$ & $\begin{array}{c}\text { Total } \\
(100 \%)\end{array}$ \\
\hline Company A & $85-93 \%$ & - & $37 \%$ & - & - & $56 \%$ \\
\hline Company B & - & - & $57 \%$ & - & - & $23 \%$ \\
\hline Group C & - & $100 \%$ & - & - & - & $13 \%$ \\
\hline Others & $7-15 \%$ & - & $6 \%$ & $100 \%$ & $100 \%$ & $8 \%$ \\
\hline Total & $100 \%$ & $100 \%$ & $100 \%$ & $100 \%$ & $100 \%$ & $100 \%$ \\
\hline
\end{tabular}

Note. Percentages of the total alcohol market are from the Excise Department and Sornpaisarn, Kaewmungkun, \& Wattanaporn (2010); percentages of the total market value of each alcohol category are from Manager Weekly Magazine (2011) and Marketeer (2008). 


\section{Data Source to Explore the Potential Stockpiling}

The analysis of potential stockpiling used data regarding alterations in alcohol production in response to tax rate changes from 1997 to 2009. Alcohol companies normally produce alcohol in a narrow range of variance over or under sales volumes each year (Sornpaisarn, Kaewmungkun, \& Wattanaporn, 2010). We calculated the differences between alcohol production and sales each year using data from the Excise Department (2012a), and then calculated the means and standard deviations of these differences for each beverage category. We then converted the absolute differences for each year into standardized differences. The standardized scores (Z-scores) of these differences for each of the eight alcoholic beverage categories were compared. For this study, extreme positive deviations of the differences one year before the taxation increase, over two-standardization differences, which is 1.645 (the statistical significance for a one-tailed 95\% confidence interval), were determined to indicate potential stockpiled production. This study could not examine the potential stockpiled production of imported alcoholic beverages and community-fermented beverages, due to a lack of data.

\section{Data Source to Explore the Influence of the Major Alcohol Companies}

The qualitative data analyses were based on case studies of two significant events, informed by three data sources, to investigate whether major alcohol companies challenged the Thai alcohol taxation system to promote tax methods that favor the positioning of their products. The first of the data sources was the active participant observation conducted by the authors from 2004 to 2009 in their capacities as Director (the first author) and Deputy Director (the second author) of Thailand's Center for Alcohol Studies (CAS), a national research center that is a reference source for media on alcohol policy issues. As the director of CAS, the first author continuously monitored, through the media, political activities regarding alcohol policies, and was interviewed by both national newspapers and television networks on alcohol policies, including a proposal by an international alcohol company in 2005 to change the Thai alcohol taxation method (i.e., the first demonstration case). The second author was the secretary of a member of the parliamentary commission considering the Excise Taxation Bill in 2007, which contained a proposal to change the current Thai alcohol taxation method (i.e., the second demonstration case). She participated in, observed and noted all significant arguments in commission meetings that discussed this proposal. The second source of data was the official minutes of parliamentary meetings at which the second author acted as secretary. These contained transcripts of all discussions that occurred in commission meetings. The third source of data was news articles regarding the politics behind alcohol policies, including both demonstration cases. Content analyses and triangulation of multiple sources of data were employed.

\section{Results}

\section{Differential Tax Rate Determination}

According to the Liquor Act of 1950 - the law concerning the production, sale, licensing, and taxation of alcoholParliament legislates taxation ceiling rates, and government departments determine taxation rates (Thailand Government Gazette, 1950). From 1992 to 2012, tax rate increases in the eight beverage categories occurred 10 times: in 1996, 1997, 1998, 2000, 2001, 2003, 2005, 2007, 2009, and 2012 (Excise Department, 2012b; see Table 2). The Thai government determined which categories would

Table 2

Pattern of ten actual tax rate increases among eight beverage categories from 1992 to 2012

\begin{tabular}{|c|c|c|c|c|c|c|c|c|c|c|}
\hline Types of alcoholic beverages & 1996 & 1997 & 1998 & 2000 & 2001 & 2003 & 2005 & 2007 & 2009 & 2012 \\
\hline 1. White spirits & & & & & & $70^{\mathrm{a}}$ & & 110 & 120 & 150 \\
\hline 2. Mixed spirits & & & & 150 & 240 & & & 280 & 300 & 350 \\
\hline 3. Special blended spirits & & & & 150 & 240 & & 400 & & & \\
\hline \multicolumn{11}{|l|}{ 4. Whisky } \\
\hline —inexpensive & & 150 & & & 240 & & 400 & & & \\
\hline —expensive & $28 \%{ }^{\mathrm{b}}$ & $35 \%$ & & & $45 \%$ & $50 \%$ & & & & \\
\hline 5. Brandy & & $25 \%$ & & & $30 \%$ & $35 \%$ & $40 \%$ & $45 \%$ & $48 \%$ & $50 \%$ \\
\hline 6. Community-fermented beverages & & & & & & 70 & & & & \\
\hline 7. Beer & & $50 \%$ & $53 \%$ & & $55 \%$ & & & & $60 \%$ & \\
\hline 8. Wine & $40 \%$ & $50 \%$ & $55 \%$ & & $60 \%$ & & & & & \\
\hline Number of categories taxed & 2 & 4 & 2 & 2 & 6 & 3 & 3 & 3 & 4 & 3 \\
\hline
\end{tabular}

Note. Numbers displayed in the table indicate the years that tax rates changed. Adapted from “Tax Statistics” by the Thai Excise Department, 2012a.

${ }^{a}$ Numbers in the table are specific tax rates in Thai Baht per liter of pure alcohol (THB/LPA).

${ }^{b}$ Percentages in the table are ad valorem tax rates for the unit of percentage of beverage prices. 
Table 3

Summary of patterns of tax increases among eight alcoholic beverage categories, in terms of proportion of the current tax rate to its ceiling rate

\begin{tabular}{|c|c|c|c|c|}
\hline Types of alcoholic beverages & $\begin{array}{c}\text { Ceiling } \\
\text { rate }\end{array}$ & $\begin{array}{l}\text { Proportion of the current rate } \\
\text { to the ceiling rate in } 1992 \\
\text { (baseline) }\end{array}$ & $\begin{array}{l}\text { Proportion of the current rate } \\
\text { to the ceiling rate in } 2012 \\
\text { (end) }\end{array}$ & $\begin{array}{c}\text { Companies that cover } \\
\text { the majority of market } \\
\text { share }\end{array}$ \\
\hline 1. White spirits & $100 \%$ & $25 \%$ & $62 \%$ & Company A \\
\hline 2. Mixed spirits & $100 \%$ & $25 \%$ & $87 \%$ & Company A \\
\hline 3. Special blended spirits & $100 \%$ & $25 \%$ & $100 \%$ & Company A \\
\hline \multicolumn{5}{|l|}{ 4. Whisky } \\
\hline —inexpensive & $100 \%$ & $25 \%$ & $100 \%$ & Company A and Group C \\
\hline —expensive & $100 \%$ & $56 \%$ & $100 \%$ & Group C \\
\hline 5. Brandy & $100 \%$ & $40 \%$ & $100 \%$ & Others \\
\hline 6. Community-fermented beverages & $100 \%$ & $100 \%$ & $70 \%^{\mathrm{a}}$ & Others \\
\hline 7. Beer & $100 \%$ & $80 \%$ & $100 \%$ & Companies B and A \\
\hline 8. Wine & $100 \%$ & $67 \%$ & $100 \%$ & Others \\
\hline
\end{tabular}

Adapted from “Tax Statistics,” by the Thai Excise Department, 2012a.

${ }^{a}$ The market share of the other low-tax-rate beverage category, the community-fermented beverages, was only $0.01 \%$ of the total alcohol market, and these beverages are not produced by the three large alcohol parties.

be affected by each increase. An average of 3.2 of the categories was affected by each tax rate increase, and the number of categories affected ranged from two in 1996 to six in 2001

\section{Tax Rate Determinations That Potentially Favor Certain Beverage Categories}

Table 3 summarizes the pattern of tax determinations for 1992 (the baseline year of the study) and 2012 (the end year of the study) among the eight beverage categories. The numbers displayed in the table represent the proportions of 1992 and 2012 tax rates to their ceiling rates for each beverage category. The actual tax rates of four beverage categories (white spirits, mixed spirits, special blend spirits, and cheap whisky) were set at much lower rates (25\% of the ceiling rate) than the other categories in the baseline year of study. The tax rates of white spirits and mixed spirits were still lower (62\% and $87 \%$ of ceiling rates) than the rates of other categories, which reached $100 \%$ of their ceiling rates by the final year of the study. These four lower-taxed products were primarily produced by Company A.

\section{Potential Stockpiled Production Before Tax Increases}

Table 4 lists the $Z$-scores of the differences between annual alcohol production over sales for each beverage category from 1997 to 2009. Eight taxation increases involved different alcohol categories during this study period: 1997, 1998, 2000, 2001, 2003, 2005, 2007, and 2009. Table 4 displays 78 alcohol category-year Z-scores (13 years * 6 beverage categories) with 35 positive scores and 43 negative scores. A positive score means production exceeded sales, and a negative score means the opposite. We observed seven Z-scores that we considered to be outliers, due to their values being greater than 1.645 and their statistical significance for one-tailed 95\% confidence interval. These scores accounted for $9 \%$ of the total number of Z-scores. Four outliers that occurred one year before three tax increases were considered to be potential stockpiled productions, as defined in this study. We also counted the overproduction of white spirits in 1999 prior to the mixed spirit tax increase in 2000 as a stockpiled production, because these two beverage categories are often substituted (Poapongskorn et al., 2007).

\section{Attempts to Challenge the Current Alcohol Excise Taxation Method in Thailand}

Four major parties were involved in the political process of challenging the current Thai alcohol taxation method: the above-mentioned three major alcohol companies, whose interests lay in commercial profits, and a network of alcohol control policy advocates, whose interests lay in public health benefits. The three major alcohol companies were not in agreement in their positions, because the proposed alcohol taxation methods provided different competitive advantages for different companies. Table 5 explains the positions of these companies. The Thai government's current alcohol taxation approach is the 2C1 taxation method with a differential tax rate policy. Company A most likely preferred to maintain this status quo, which we have termed "Political Position 1," because it gave Company A a competitive advantage. Because Company B and Group C had no such competitive advantage, they preferred changes to both the current taxation method and the differential tax rate policy, referred to here as "Political Position 2." Company B and Group C attempted to advocate for a specific taxation method to replace the 2C1 taxation method, because lower tax rates would be imposed upon their products, thereby reducing prices and potentially resulting in higher sales volumes (Sornpaisarn et al., 2012a, 2012b). The network of alcohol 
Table 4

Standardized (Z) scores of the different amounts of yearly alcohol production over sales for eight alcoholic beverage categories from 1997 to 2009

\begin{tabular}{|c|c|c|c|c|c|c|c|c|}
\hline $\begin{array}{c}\text { Corporate } \\
\text { share of each } \\
\text { category }\end{array}$ & & $93 \%$ of & $\begin{array}{l}\text { iny A: } \\
\text { tic spirits }\end{array}$ & & $\begin{array}{c}\text { Group C: } \\
100 \% \text { of } \\
\text { imported } \\
\text { whisky } \\
\text { market }\end{array}$ & Others & Others & $\begin{array}{c}\text { Company B: } \\
57 \% \text {; } \\
\text { Company A: } \\
37 \% \text { of beer } \\
\text { market }\end{array}$ \\
\hline $\begin{array}{c}\text { Beverage } \\
\text { category }\end{array}$ & $\begin{array}{l}\text { White } \\
\text { spirits }\end{array}$ & $\begin{array}{l}\text { Mixed } \\
\text { spirits }\end{array}$ & $\begin{array}{c}\text { Special } \\
\text { blend } \\
\text { spirits }\end{array}$ & $\begin{array}{c}\text { Domestic } \\
\text { whisky } \\
\text { (including } \\
\text { brandy) }\end{array}$ & $\begin{array}{c}\text { Imported } \\
\text { whiskies }\end{array}$ & $\begin{array}{c}\text { Community- } \\
\text { fermented } \\
\text { beverages }\end{array}$ & Wine & Beer \\
\hline \multicolumn{9}{|l|}{ Year } \\
\hline 1997 & 0.58 & -0.15 & $1.66^{\mathrm{a}}$ & $0.08^{\mathrm{a}}$ & $\mathrm{NA}^{\mathrm{c}}$ & NA & $-1.06^{\mathrm{b}}$ & $-0.81^{\mathrm{b}}$ \\
\hline 1998 & 0.83 & -1.69 & $2.17^{\mathrm{a}}$ & -0.27 & NA & NA & -1.10 & -0.84 \\
\hline 1999 & $2.03^{\mathrm{a}}$ & $2.19^{\mathrm{a}}$ & 0.84 & 0.97 & NA & NA & 0.16 & -0.78 \\
\hline 2000 & -1.73 & $-1.65^{b}$ & $0.32^{\mathrm{b}}$ & 0.60 & NA & NA & -0.54 & -0.58 \\
\hline 2001 & -1.44 & $-0.69^{b}$ & $-0.48^{b}$ & $-2.06^{\mathrm{b}}$ & NA & NA & $1.39^{\mathrm{b}}$ & $-0.67^{\mathrm{b}}$ \\
\hline 2002 & -0.11 & -0.41 & -0.47 & -1.54 & NA & NA & -0.53 & -0.53 \\
\hline $2003^{d}$ & $-0.31^{b}$ & 0.09 & -1.17 & -0.26 & $\mathrm{NA}^{\mathrm{b}}$ & $\mathrm{NA}^{\mathrm{b}}$ & -1.67 & -0.49 \\
\hline 2004 & 1.14 & 0.45 & -0.79 & $1.91^{\mathrm{a}}$ & NA & NA & -0.45 & -0.60 \\
\hline 2005 & -0.35 & 0.29 & $-0.62^{b}$ & $0.32^{b}$ & NA & NA & 0.74 & 0.09 \\
\hline 2006 & -0.24 & 0.41 & -0.80 & 0.07 & NA & NA & 0.98 & 0.58 \\
\hline 2007 & $-0.15^{b}$ & $0.45^{\mathrm{b}}$ & -0.38 & -0.09 & NA & NA & 0.80 & 0.79 \\
\hline 2008 & -0.38 & 0.21 & -0.32 & -0.15 & NA & NA & 1.41 & $2.03^{\mathrm{a}}$ \\
\hline 2009 & $0.15^{\mathrm{b}}$ & $0.51^{\mathrm{b}}$ & 0.04 & 0.41 & NA & NA & -0.10 & $1.81^{\mathrm{a}, \mathrm{b}}$ \\
\hline \multicolumn{9}{|l|}{$\begin{array}{l}\text { Mean (LPA } \\
\text { per capita per }\end{array}$} \\
\hline year) & -0.60 & -0.25 & -0.01 & -0.01 & 0.00 & 0.00 & 0.03 & 0.24 \\
\hline SD & 1.4 & 0.6 & 0.1 & 0.3 & 0.0 & 0.0 & 0.01 & 0.3 \\
\hline
\end{tabular}

Note. The eight categories in Table 4 are arranged according to the sales data available from the Thai Excise Department. Brandy is included in the domestic whisky category; imported whisky is excluded from the inexpensive whisky category. Adapted from "Tax Statistics," by the Thai Excise Department, 2012a.

Bold figures are hypothesized as potentially stocked productions.

${ }^{a}$ Standardized score greater than two standard deviations (1.645) for a one-tailed 95\% confidence interval.

${ }^{\mathrm{b}}$ Represents the years in which tax rates of a particular beverage category increased.

${ }^{\mathrm{c} B e c a u s e ~ o n l y ~ p r o d u c t i o n ~ d a t a ~ a n d ~ n o t ~ s a l e s ~ d a t a ~ w e r e ~ a v a i l a b l e ~ f o r ~ c o m m u n i t y-f e r m e n t e d ~ b e v e r a g e s ~ a n d ~ i m p o r t e d ~ s p i r i t s, ~ t h e s e ~ c a t e g o r i e s ~ c a n n o t ~}$ be used to demonstrate stocked production.

${ }^{\mathrm{d}}$ In 2003, taxes on white spirits and community-fermented beverages were lowered.

\section{Table 5}

Political positions regarding the proposal for changes to the Thai alcohol taxation system among the three largest parties of the Thai alcohol market

\begin{tabular}{|c|c|c|c|c|}
\hline & \multicolumn{2}{|c|}{$\begin{array}{l}\text { Political position regarding the } \\
\text { proposal for changes to the Thai } \\
\text { alcohol taxation system }\end{array}$} & \multirow[b]{2}{*}{$\begin{array}{l}\text { Political } \\
\text { position }\end{array}$} & \multirow[b]{2}{*}{ Rationale behind } \\
\hline & $\begin{array}{l}\text { Change the } \\
\text { current taxation } \\
\text { method }\end{array}$ & $\begin{array}{l}\text { Change the } \\
\text { differential tax } \\
\text { rate policy }\end{array}$ & & \\
\hline Company A & No & No & 1 & Company A has competitive advantages over the status quo. \\
\hline $\begin{array}{l}\text { Alcohol } \\
\text { control } \\
\text { policy } \\
\text { advocates }\end{array}$ & No & Yes & 3 & $\begin{array}{l}\text { The current taxation method (2C1) is better than specific taxation for the } \\
\text { Thai context, in which lifetime abstainers are prevalent. The consumption } \\
\text { situation among adolescents will be worse under specific taxation than under } \\
2 \mathrm{C} 1 \text { taxation. However, the uniform tax rate policy will provide both a fair } \\
\text { competition context for all alcohol companies and consumption control } \\
\text { effectiveness for the government, because it will not encourage substitute } \\
\text { consumption in lower-taxed alcohol categories. }\end{array}$ \\
\hline
\end{tabular}


control policy advocates preferred to maintain the 2C1 taxation method, because it can reduce alcohol consumption and prevent adolescents from beginning to drink, which is appropriate in Thailand, where there is a high prevalence of lifetime abstainers (Sornpaisarn et al., 2012a, 2012b). However, the advocates preferred a uniform tax rate policy, to ensure fair competition for all alcohol companies and improve the effectiveness of taxation policy by not encouraging consumers to substitute lower-taxed beverage categories. The position of the alcohol control advocates is termed "Political Position 3."

The following is a summary of two significant events in Thailand which demonstrated that Group C (Case 1) and Company B (Case 2) challenged the current alcohol taxation system in order to promote tax methods that would favor the positioning of their products. (For full details of both cases, see the Appendix.)

With respect to Case 1, the largest import company, which is in Group C, obtained access to the Thai Prime Minister in early 2005 after it donated a large amount of money to help the government with tsunami relief. The company's Australia-based researchers provided information which argued for a change in the current alcohol taxation system in order to protect consumers' health. The proposed tax method would result in lower taxation of the company's products, but this fact was not mentioned. The Prime Minister intended to publicly support this proposal, but his cabinet dissolved before the tax system was changed.

With respect to Case 2, Company B's alliance with a member of the National Legislative Council influenced the parliamentary process by which the Excise Taxation Bill, which proposed a change to the current alcohol taxation method, was considered. Two unusual events occurred. First, a member of Parliament called seven meetings of the parliamentary commission considering this bill over a fourweek period. Although he failed to advocate successfully for changing the tax method, which would have provided the most benefit for Company B, he was more successful in his support of the second-most favorable option: the equal tax rate. A proposal for this change was registered for official consideration in Parliament for the final step towards becoming national legislation; however, in the second unusual event, the proposal was removed from the parliamentary agenda on the last day the term (i.e., December 21, 2007), resulting in the dismissal of the entire excise bill. No explanation was provided for the removal of the bill.

\section{Discussion}

Previous studies concerning the politics of alcohol policy have primarily explored how the alcohol industry as a whole influences governments in the setting and framing of their alcohol policy agenda (Babor, 2004, 2006; Baggott, 2010; Giesbrecht, 2006; Hawkins \& Holden, 2013; Hawkins et al., 2012; Hawks, 1993; Jernigan, 2012; Room, 2004), as well as what strategies and tactics the alcohol industry employs to influence policy makers (Holden et al.,
2012; McCambridge et al., 2013). In contrast, our study addressed the interactions between alcohol companies and the Thai government.

After the baseline of this study in 1992 and until the study's end year in 2012, the Thai government employed differential tax rates which favored four types of alcoholic beverage-produced, for the most part, by one large company (see Table 3). The rationale given by the Thai government for the regular alcohol tax increases was either to reduce alcohol consumption or to generate tax revenue. However, because the differential tax rate policy had the potential to favor certain alcoholic beverage categories, it encouraged some consumers to shift their beverage choices toward the lower taxed and priced beverages, thereby lowering its effectiveness in reducing alcohol consumption (Gruenewald, Ponicki, Holder, \& Romelsjö, 2006; Ponicki, Holder, Gruenewald, \& Romelsjö, 1997). This situation is similar to one in Hong Kong, where the government lowered tax rates on wine and beer but maintained a high tax rate for spirits, which shifted consumption from spirits to wine and beer (Yoon \& Lam, 2012).

Reviewing eight alcohol taxation increases from 1997 to 2009, this study detected three incidences of potential stockpiling of alcohol products one year before a tax increase (see Table 4). This stockpiling is similar to a situation described in the WHO Technical Report on Tobacco Tax Administration, whose authors argue that when tobacco manufacturers, wholesalers, or retailers expect a tax increase, they may stockpile cigarettes to capitalize on the current lower tax level (World Health Organization, 2010b).

Our findings confirm the study of Holden et al. (2012), which argues that the alcohol industry includes several subsectors that have diverse and conflicting business positions and interests (Holden et al., 2012). The major alcohol companies that were disadvantaged by the Thai differential tax rate policies tried to challenge the current method of taxation. Had they been successful, the tax rates levied on their products might have been lowered or made equal to those of their competitors, which would have improved their competitive advantage. Conversely, Company A, which benefited from the current method of taxation, never challenged any government decisions regarding alcohol taxation. This behavior indicates that alcohol companies advocate for taxation policies that favor the positions of their products.

This study has two limitations. First, there is a lack of sales data for imported alcoholic beverages and communityfermented beverages. Thus, we could not examine the potential stockpiling of these two beverage categories (see Table 4); however, no incidences of unusual over- or under-production and importation were detected in either beverage category during the study period (Sornpaisarn, Kaewmungkun, \& Wattanaporn, 2010). Second, there is a lack of more comprehensive sources of data, beyond the two case studies of political events discussed above, that examine challenges to Thailand's alcohol taxation system. 
Future research into the role of politics in the alcohol policy process should examine how the alcohol industry accesses policy makers, the details of the strategies and tactics it uses to successfully lobby policy makers, how reciprocal relationships are established, and the offering of financial and political incentives. It should be noted that studying these topics in the alcohol policy field is more challenging than in the tobacco policy field, where researchers have access to internal industry documents pertaining to government policy (Hawkins et al., 2012). Access to internal alcohol industry documents pertaining to government policy would allow for a much more accurate and in-depth analysis of the role of the alcohol industry in the policy process.

In conclusion, evidence suggests that large domestic and international alcohol companies in Thailand likely exert political influence on Thailand's alcohol taxation system. They may influence the differential alcohol tax rate policy to favor their products, be able to stockpile their products before tax rate increases, and have significant power to challenge the alcohol taxation system at the national level through the federal government and Parliament.

\section{References}

Babor, T. F. (2004). Admirable ends, ineffective means: Comments on the alcohol harm reduction strategy for England. Drugs: Education, Prevention and Policy, 11, 361-365.

Babor, T. F. (2006). Diageo, University of College Dublin and the integrity of alcohol science: It's time to draw the line between public health and public relations. Addiction, 101, 1375-1377.

Babor, T. F., Caetano, R., Casswell, S., Edwards, G., Giesbrecht, N., Graham, K., . . . Rossow, I. (2010). Alcohol: No ordinary commodity. Research and public policy (2nd ed.). Oxford, England: Oxford University Press.

Babor, T. F., \& Robaina, K. (2013). Public health, academic medicine, and the alcohol industry's corporate social responsibility activities. American Journal of Public Health, 103, 206-214.

Baggot, R. (2010). A modern approach to an old problem? Alcohol policy and New Labour. Policy \& Politics, 38, 135-152.

Elder, R. W., Lawrence, B., Ferguson, A., Naimi, T. S., Brewer, R. D., Chattopadhyay, S. K., . . . Fielding, J. E. (2010). The effectiveness of tax policy interventions for reducing excessive alcohol consumption and related harms. American Journal of Preventive Medicine, 38, 217-229.

Excise Department. (2012a). Tax statistics. Retrieved from http://www.excise.go.th/index.php?id=1

Excise Department. (2012b). Ministerial regulations issued according to the Alcohol Control Act 1950. Retrieved from http://law.excise.go.th/exciselaw/showdataL1.jsp

Giesbrecht, N. (2006). Alcohol policy in Canada: Reflections on the role of the alcohol industry. Nordic Studies on Alcohol and Drugs, 23, 445-466.
Gruenewald, P. J., Ponicki, W. R., Holder, H. D., \& Romelsjö, A. (2006). Alcohol prices, beverage quality, and the demand for alcohol: Quality substitutions and price elasticities. Alcoholism Clinical and Experimental Research, 30, 96-105.

Hastings, G. (2013). Why corporate power is a public health priority. British Medical Journal, 345, e5124.

Hawkins, B., \& Holden, C. (2013). Framing the alcohol policy debate: Industry actors and the regulation of the UK beverage alcohol market. Critical Policy Studies, 7, 53-71.

Hawkins, B., \& Holden, C. (2014). 'Water dripping on stone'? Industry lobbying and UK alcohol policy. Policy \& Politics, 42, 55-70.

Hawkins, B., Holden, C., \& McCambridge, J. (2012). Alcohol industry influence on UK alcohol policy: A new research agenda for public health. Critical Public Health, 22, 297-305.

Hawks, D. (1993). The formulation of Australia's National Health Policy on Alcohol. Addiction, 88, 19S-26S.

Holden, C., Hawkins, B., \& McCambridge, J. (2012). Cleavages and co-operation in the UK alcohol industry: A qualitative study. BMC Public Health, 12, 483.

Jernigan, D. H. (2012). Global alcohol producers, science, and policy: The case of the International Center for Alcohol Policies. American Journal of Public Health, 102, 80-89.

Keen, M. (1998). The balance between specific and ad valorem taxation. Fiscal Studies, 19, 1-37.

Kunnathum, J., Makka, N., Aungkulanon, S., Amornvisaisoradej, C., \& Nundhamcharoen, K. (2013). A comparative risk assessment of health burden attributable to modifiable risk factors in Thailand, 2009: A systematic analysis. The Lancet, 381 , S78.

Marketeer. (2008, June). Retrieved from http://www. marketeer.co.th/inside_detail.php?inside_id=6358

McCambridge, J., Hawkins, B., \& Holden, C. (2013). Industry use of evidence to influence alcohol policy: A case study of submissions to the 2008 Scottish government consultation. PLoS Medicine, 10, e1001431.

McCambridge, J., Hawkins, B., \& Holden, C. (2014). Vested interests in addiction research and policy. The challenge corporate lobbying poses to reducing society's alcohol problems: Insights from UK evidence on minimum unit pricing. Addiction, 109, 199-205.

Poapongsakorn, N., Leehanon, S., Laowakun, D., Tasarika, A., Methasurarak, S., \& Jittareekunm, T. (2007). Assessment of the impact of liquor taxes on prices and consumption of liquor. Bangkok, Thailand: Center for Alcohol Studies.

Ponicki, W. R., Holder, H. D., Gruenewald, P. J., \& Romelsjö, A. (1997). Altering alcohol price by ethanol content: Results from a Swedish tax policy in 1992. Addiction, 92, 859-870.

Rehm, J., Mathers, C., Popova, S., Thavorncharoensap, M., Teerawattananon, Y., \& Patra, J. (2009). Global burden of disease and injury and economic cost attributable to alcohol use and alcohol-use disorders. The Lancet, 373, 2223-2233. 
Report: Watch alcohol tax rate change: Who gains benefit between domestic and international companies. Manager Online. (2005, June 28). Retrieved from http://www.manager.co.th/Business/ViewNews.aspx? NewsID=9480000074822

Room, R. (2004). Disabling the public interest: Alcohol strategies and policies for England. Addiction, 99, 1083-1089.

Schlager, E., \& Blomquist, W. (1996). A comparison of three emerging theories of the policy process. Political Research Quarterly, 49, 651.

Sornpaisarn, B., Kaewmungkun, C., \& Wattanaporn, K. (2010). Annual report on alcohol 2010. Nonthaburi Province, Thailand: Center for Alcohol Studies.

Sornpaisarn, B., Shield, K., Cohen, J., Schwartz, R., \& Rehm, J. (2013). Elasticity of alcohol consumption, alcohol-related harms, and drinking initiation in lowand middle-income countries: A systematic review and meta-analysis. International Journal of Drug and Alcohol Research, 2, 1-14.

Sornpaisarn, B., Shield, K., \& Rehm, J. (2012a). Alcohol taxation policy in Thailand: Implications for other low- to middle-income countries. Addiction, 107, 1372-1384.

Sornpaisarn, B., Shield, K., \& Rehm, J. (2012b). Twochosen-one taxation: Examining its potential effectiveness to reduce drinking initiation and heavy alcohol consumption in low- and middle-income countries. Addiction, 107, 1389-1390.

Tesler, T.E., \& Malone, R.E. (2008). Corporate philanthropy, lobbying, and public health policy. American Journal of Public Health, 98, 2123-2132.
The Liquor Act 1950. (1950). Thailand Government Gazette, 76(16). Retrieved from http://www.krisdika. go.th/wps/portal/general/!ut/p/c5/04_SB8K8xLLM9M SSzPy8xBz9CP0os3g_A2czQ0cTQ89ApyAnA0_EI OAQGdXAwMLE30_j_zcVP2CbEdFAIfszEk!/dl3/d3 /L0lDU0lKSWdra2trIS9JSFJBQUlpQ2dBek15cXhtLz RCRWo4bzBGbEdpdC1iWHV3RUEhLzdfTjBDNjF BNDFJQUJRNjBJRVVRMTBEMDIwRzAvc2Euc3B

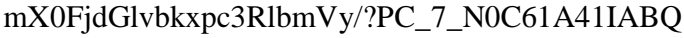
60IEUQ10D020G0_spf_strutsAction=!2fsearch.do

Wagenaar, A. C., Salois, M. J., \& Komro, K. A. (2009). Effects of beverage alcohol price and tax levels on drinking: A meta-analysis of 1003 estimates from 112 studies. Addiction, 104, 179-190.

Winning strategy over Singh, Chang changes its game: Brand building strategy instead of sale strategy. Manager Weekly Magazine. (2011, January 13). Retrieved from http://www.manager.co.th/mgrweekly/ viewnews.aspx?newsID=9540000004495

World Health Organization. (2010a). Global strategy to reduce the harmful use of alcohol. Geneva, Switzerland: Author.

World Health Organization. (2010b). WHO technical manual on tobacco tax administration. Geneva, Switzerland: Author.

Yoon, S., \& Lam, T.H. (2012). The alcohol industry lobby and Hong Kong's zero wine and beer tax policy. BMC Public Health, 12, 717.

\section{Appendix}

The following are two significant events, described as case studies, which demonstrate that Group C (case 1) and Company B (case 2) challenged the current alcohol taxation system to promote tax methods that would favor the positioning of their products.

Case 1. In early 2005, a large international alcohol company (a company in Group C), which had the largest market share of imported alcoholic beverages in Thailand, invited representatives of CAS (the first author and the second author) and the Thai Excise Department to attend a presentation addressing the problems caused by the Two-Chosen-One (2C1) taxation system, a unique alcohol excise tax enforced by the Thai government since 1950 (Sornpaisarn et al., 2012a). The company arranged the meeting. Australian researchers, who were invited by the company, explained that under the 2C1 taxation system, higher excise tax rates were applied to expensive imported whiskies than to inexpensive domestic distilled beverages, thus emphasizing revenue generation over consumer health protection. As a result, in their opinion, more inexpensive, low-quality whiskies (aged for only a few years) were consumed in Thailand. The researchers claimed that these inexpensive, low-quality whiskies were worse for consumer health than were expensive, high-quality whiskies, which are aged longer.

Moreover, the vice president of the alcohol company also told the authors that company representatives were able to meet with the Thai Prime Minister; this information was conveyed after her company donated a large amount of money to the Thai government in early 2005, in response to the tsunami that struck the southern part of Thailand on December 26, 2004. The team of researchers from the presentation attended by the authors subsequently presented those same research conclusions to the Thai Prime Minister. Later, the Prime Minister announced in his weekly public radio address on May 28, 2005 (Manager Online, 2005) that he was interested in changing the system of alcohol excise taxation-2C1 taxation - to specific taxation because he wanted the Thai people to drink less alcohol and was more concerned with their health than with alcohol excise tax revenue- the same rationale offered by the Australian research team. For political reasons, the Prime Minister's position changed before the taxation system did.

Case 2. In 2007, Parliament considered a bill, proposed by the Excise Department, that aimed to expand the excise taxation ceiling rates of several goods, including alcohol. This move would allow increased tax rates for several beverage categories, but in the view of Company B, this would not solve the problems caused by the current taxation system. 
Many discussions ensued during the consideration process, with contributions mainly from three parties: (1) representatives from the Excise Department, (2) Mr. S (an ally of Company B), and (3) the representative of CAS. (Mr. S is here defined as an ally of Company B because his proposals for change were always beneficial to Company B.) The Excise Department representatives defended the first political position: maintaining the status quo of the Thai alcohol taxation system (hereafter called "P1"). Mr. S defended the second political position: a proposal for change from 2C1 taxation to specific taxation (hereafter called "P2"). The representative of CAS defended the third political position: preserving 2C1 taxation with a uniform tax rate policy (hereafter called "P3"). P1 proposed the expansion of taxation ceiling rates, but ignored the problems in the alcohol market caused by existing unequal tax rates, which Company B perceived to be advantageous to Company A. P2 proposed changing the current taxation system (2C1) to specific taxation, which supporters argued would balance the competitive advantages between Companies A and B. However, the advocates of P2 hid the fact that the tax rates for beer would be greatly reduced, which would result in higher sales of beer-the main product of Company B. P3 tried to preserve the current taxation method (2C1), because $2 C 1$ is an appropriate taxation method for Thailand, where lifetime abstention from alcohol consumption is prevalent, and because 2C1 helps to reduce alcohol consumption and prevent drinking initiation among adolescents (Sornpaisarn et al., 2012a).

P2 primarily sought to change the current taxation system, whereas P1 and P3 preferred to preserve it; thus, since votes for P1 and P3 outnumbered votes for P2, the current taxation system was preserved. However, P2 also sought to resolve the unfairness of differential tax rates in the alcohol market, and P3 was not against this proposition. Thus, a new intervention, the equal tax rate policy, was proposed. This proposal suggested establishing a minimum tax rate for specific taxation under $2 \mathrm{C} 1$ taxation that equalized the competitive advantage between Company A and B, which meant that Company A would effectively lose its competitive advantage. After many discussions in seven sub-commission meetings over four weeks, the majority of the subcommission agreed upon the new intervention proposal, and it was registered for further legal consideration in the Thai Parliament.

However, an unusual event occurred: this proposal was removed, with no reasons provided, from the parliamentary lawconsideration agenda on the last day of Parliament's term, December 21, 2007. The entire excise bill was ultimately dismissed. Mr. S of P2 was highly critical of the hidden parliamentary processes that led to this outcome. The circumstances of, and motives for, the bill's removal are not known; however, Company A benefited from the disappearance of this law. 